\title{
B-type natriuretic peptide in the evaluation of cardiac function
}

\section{Peptídeo natriurético tipo B na avaliação da função cardíaca}

Adriana Polachini do Valle; Paulo José Fortes Villas Boas'; Edison Iglesias de Oliveira Vidal²; Fernanda Bono Fukushima ${ }^{3}$

\begin{abstract}
B type natriuretic peptide (BNP) and its precursor, the inactive form of NT-pro-BNP, are currently the most studied laboratory parameters in the heart disease spectrum. The assessment of their blood concentrations provides invaluable information on the likelihood, severity and prognosis of the disease. The present review aims to describe the biological determinants, the factors that influence these peptide concentrations, the suggested cutoff values for the diagnosis of heart failure and the use of this biomarker in the assessment of cardiac function.
\end{abstract}

Key words: B-type natriuretic peptide; cardiac function.

\section{INTRODUCTION}

The natriuretic peptide family consists of atrial natriuretic factor (ANF), brain natriuretic peptide, also called type B (BNP), and C-type natriuretic peptide (CNP). These peptides play an important role in cardiovascular homeostasis and modulation of cell growth. The messenger ribonucleic acid (mRNA) of the atrial natriuretic factor has been found in many tissues, although it is particularly abundant in the cardiac atria. BNP was initially isolated from brain homogenates, but it is also detected in the peripheral circulation. Its highest concentration is in the myocardial tissue. Both ANF and BNP are normally produced by atrial muscle cells, from where they are released. Under atypical conditions, such as myocardial structural disease, BNP seems to be produced on a larger scale by the ventricles ${ }^{(28)}$.

The action of natriuretic peptides is part of a complex neurohormonal structure which includes the effects of both the renin-angiotensin-aldosterone system (RAAS) and the autonomic nervous system. In response to distension of the atrial tissue, there is an increase in ANF and BNP plasma concentrations, which antagonize the effects of angiotensin II in vascular tone, aldosterone secretion, sodium reabsorption and vascular cell growth. CNP found predominantly in the brain and in endothelial cells presents very low plasma concentrations ${ }^{(34)}$. Therefore, ANF and BNP are the most commonly investigated, mainly in cardiovascular diseases.

The production and release of these peptides occur in response to three different stimuli. First, as an acute response to myocardial muscle stretch with secretion of peptides stored in the atrium. A second stimulus for the production of peptides is observed during mineralocorticoid excess, which is denominated as a "subacute" phenomenon and secondary to volume overload. Finally, due to the chronic volume overload, there is a coexistence of cardiac gene reprogramming associated with ventricular hypertrophy, leading to major changes in the synthesis, storage and release of ventricular peptides ${ }^{(10)}$.

First submission on $05 / 11 / 12$; last submission on $05 / 11 / 12$; accepted for publication on 12/12/12; published on 20/08/13

1. Doctor in Clinical Physiopathology by Universidade Estadual Paulista (UNESP); professor at UNESP-Medical School, Botucatu.

2. Doctor in Collective Health by Universidade Estadual de Campinas (UNICAMP); professor at UNESP-Medical School, Botucatu.

3. Doctor in Anesthesiology by UNESP; professor at UNESP-Medical School, Botucatu. 


\section{BIOCHEMISTRY OF NATRIURETIC PEPTIDES}

The main biochemical and physiological characteristics of the peptides are shown in Table $\mathbf{1}$.

\section{BIOLOGICAL DETERMINANTS OF BNP CONCENTRATIONS}

Blood levels of natriuretic peptides are affected by several physiological factors such as circadian rhythm, age, exercise, and body posture. The factors that contribute to increased concentrations of the peptide due to the aging process are cardiac and renal functions typical of senescence, reduced degradation of peptides and development of resistance to the action of peptides in the target organs, namely kidney, leading to a significantly higher production of BNP ${ }^{(12)}$. Furthermore, the most common cardiac alterations in the elderly, namely left atrial enlargement, increased afterload and presence of diastolic dysfunction, may interfere in peptide plasma levels ${ }^{(13,22)}$.

Several drugs, including diuretics, angiotensin-converting enzyme (ACE) inhibitors, adrenergic agonists as well as sex, thyroid and glucocorticoid hormones may modify the circulating levels of natriuretic peptides ${ }^{(30)}$.

Serum concentrations of BNP are higher in women than in men in the absence of cardiac dysfunction ${ }^{(27)}$. This increase could be related to estrogen levels, since it was observed higher peptide levels in women who underwent hormone replacement therapy. Another study suggested that there would be a partial suppression of BNP secretion and of inactive N-terminal pro-BNP (NT-pro-BNP) associated with levels of free teststerona, substantiating lower peptide levels in men.
It is suggested that specific reference values for age and gender should be applied to the interpretation of BNP values.

\section{COMORBIDITIES THAT INFLUENCE THE INTERPRETATION OF BNP CONCENTRATIONS}

The presence of obesity may interfere in BNP levels, inasmuch as adipose tissue is closely related to receptors that participate in the degradation of circulating natriuretic peptides ${ }^{(29)}$. Higher cut-off values are recommended for the diagnosis of heart failure (HF) in obese patients ${ }^{(4)}$.

The presence of renal failure may increase BNP values and higher cutoff values should be adopted for the detection of $\mathrm{HF}$ in advanced chronic renal patients ${ }^{(24)}$.

Patients with chronic renal disease are prone to an increase in atrial pressure, systemic pressure and ventricular mass, situations in which a rise in the synthesis and secretion of BNP would be expected $^{(24)}$. Renal excretion of BNP has been described, but alterations in the circulating levels in renal disease patients are more likely related to the reduction of clearance by natriuretic peptide receptor $\mathrm{C}(\mathrm{NPR}-\mathrm{C})$ and neutral endopeptidase (NEPs) ${ }^{(7)}$.

Concomitant lung disease does not diminish the usefulness of distinguishing patients with or without HF. However, it is important to consider that BNP is elevated in one third of cases of pulmonary embolism. This rise accounts for the increase in right ventricular pressure and indicates a worse prognosis for pulmonary embolism ${ }^{(31)}$. In cases of chronic pulmonary hypertension without cardiac volume overload, expected BNP values range from 100 to $500 \mathrm{pg} / \mathrm{ml}^{(17)}$.

TABLE 1 - Biochemical and physiological characteristics of natriuretic peptides ${ }^{(5)}$

\begin{tabular}{ccc}
\hline Peptide & ANF & BNP \\
\hline Chain & 28 aa & 32 aa \\
Receptor & NPR-A, NPR-C & NPR-A, NPR-C \\
Precursor & Pre-pro-ANF $(151 \mathrm{aa})$ & Pre-pro-BNP $(134 \mathrm{aa})$ \\
Pro-hormone & Pro-ANF(125 aa) & Pro-BNP $(108 \mathrm{aa})$ \\
Pro-hormone storage & Atrial granules & Secreted mainly in the ventricle without storage \\
Highly circulating Peptide fragment & NT-pro-ANF, ANF & BNP \\
Biologically active hormone & ANF & 21 minutes \\
Plasma half-life & 3 minutes & Ventricular wall tension \\
Release stimulus & Atrial transmural tension & Cardiac atrium and ventricle \\
Synthesis & Cardiac atrium &
\end{tabular}

aa: aminoacids; BNP: B natriuretic peptide; ANF: atrial natriuretic factor; NPR-A: natriuretic peptide receptor A; NPR-C: natriuretic peptide receptor C; NT-pro-ANF: inactive $N$ terminal pro atrial natriuretic factor. 


\section{BNP AND NT-PRO-BNP}

BNP is synthesized as pre-pro-BNP, especially in the ventricular myocardium. In the myocyte, pre-pro-BNP is cleaved by enzymatic action on pro-BNP and released as BNP (active form) and NT-proBNP (inactive form). Both BNP and NT-pro-BNP levels indicate the severity of heart failure, but there are differences between the two tests as to the influence of age and renal function. BNP is cleared from the plasma by glomerular filtration and also by endopeptidase degradation. In contrast, NT-pro-BNP may be eliminated exclusively by glomerular filtration, hence the strong influence of renal function on NT-pro-BNP concentrations. As a decrease in glomerular filtration rate occurs with age, the diagnostic cutoff value for NT-pro-BNP is age dependent. The same applies to BNP, but with lower intensity ${ }^{(23)}$.

Both peptides are usually higher in patients on hemodialysis treatment even in the absence of circulating volume overload ${ }^{(32)}$.

Despite these limitations, a study evaluating the effectiveness of natriuretic peptides in clinical practice demonstrated that both BNP and NT-pro-BNP are useful tools in the management to heart failure $^{(19)}$.

Table 2 presents the currently available tests and Table 3 shows further information on them.
Table $\mathbf{4}$ shows the recommended BNP and NT-pro-BNP cutoff concentrations for the diagnosis of $\mathrm{HF}^{(15)}$.

TABLE 2 - Commercially available tests for assessing natriuretic peptides

\begin{tabular}{cc}
\hline BNP & $\begin{array}{c}\text { NT-pro-BNP } \\
\text { (using Biosite reagents ) }\end{array}$ \\
\hline Biosite & Roche \\
Bayer (Siemens) & Dade Bhering (Siemens) \\
Abbott & Ortho-Clinical Diagnostics (J\&J) \\
Beckman Couter & Nanogen \\
\hline
\end{tabular}

BNP: B natriuretic peptide; NT-pro-BNP: inactive N terminal pro BNP.

TABLE 3 - Information on essays

\begin{tabular}{ccc}
\hline & NT-pro-BNP & BNP \\
\hline Sample type & Plasma or serum & Plasma \\
Tube type & Glass or plastic & Plastic tube \\
Plasma half-life & $60-120$ minutes & 20 minutes \\
Stability of EDTA & Until 2 days at room & 4 hours in room \\
(plasma) & temperature & temperature \\
Analytical sensitivity & Higher & Lower \\
\hline
\end{tabular}

BNP: B natriuretic peptide; NT-pro-ANF: inactive N terminal pro atrial natriuretic factor; EDTA: ethylenediaminetetraacetic acid.

TABLE 4 - Recommended BNP and NT-pro-BNP cutoff values for the diagnosis of HF

\begin{tabular}{|c|c|c|c|c|c|c|}
\hline & & Cutoff value (pg/ml) & Sensitivity (\%) & Specificity (\%) & PPV (\%) & NPV (\%) \\
\hline \multirow{2}{*}{ Exclusion of HF } & BNP & $<50$ & 97 & 62 & 71 & 96 \\
\hline & NT-pro-BNP & $<300$ & 99 & 68 & 62 & 99 \\
\hline \multirow{2}{*}{$\begin{array}{l}\text { Identify HF with a } \\
\text { single cutoff value }\end{array}$} & BNP & 100 & 90 & 76 & 79 & 89 \\
\hline & NT-pro-BNP & 900 & 90 & 85 & 76 & 94 \\
\hline \multirow{6}{*}{$\begin{array}{l}\text { Identify HF with } \\
\text { multiple cutoff values }\end{array}$} & \multirow{3}{*}{ BNP } & $<100$ for exclusion & 90 & 73 & 75 & 90 \\
\hline & & 100-400 grey zone & - & - & - & - \\
\hline & & $>400$ diagnosis & 63 & 91 & 86 & 74 \\
\hline & \multirow{3}{*}{$\begin{array}{c}\text { NT-pro-BNP } \\
\text { stratified by age }\end{array}$} & $<450$ for $<50$ years & 90 & 84 & 88 & 66 \\
\hline & & $<900$ from 50 to 75 years & 90 & 84 & 88 & 66 \\
\hline & & $<1,800$ for $>75$ years & 90 & 84 & 88 & 66 \\
\hline \multirow{2}{*}{$\begin{array}{l}\text { Special situations: } \\
\text { renal dysfunction } \\
\text { (glomerular filtration } \\
<60 \mathrm{ml} / \mathrm{min} \text { ) }\end{array}$} & BNP & $<200$ & 88 & 63 & 83 & 72 \\
\hline & NT-pro-BNP & $<1,200$ & 89 & 72 & 74 & 94 \\
\hline \multirow{4}{*}{$\begin{array}{l}\text { Special situations: } \\
\text { obesity }\end{array}$} & \multirow{3}{*}{ BNP } & 170 for $\mathrm{BMI}<25 \mathrm{~kg} / \mathrm{m}^{2}$ & 90 & 77 & 78 & 90 \\
\hline & & 110 for BMI $25-35 \mathrm{~kg} / \mathrm{m}^{2}$ & 90 & 77 & 77 & 90 \\
\hline & & 54 for BMI $>35 \mathrm{~kg} / \mathrm{m}^{2}$ & 91 & 70 & 70 & 91 \\
\hline & NT-pro-BNP & $<900$ & 87 & 76 & 79 & 90 \\
\hline
\end{tabular}

BNP: B natriuretic peptide; NT-pro-ANF: inactive N terminal pro atrial natriuretic factor; HF: cardiac failure; PPV: positive predictive value; NPV: negative predictive value; HF: cardiac failure; BMI: body mass index. 


\section{BNP IN THE ASSESSMENT OF CARDIAC FUNCTION}

Many studies have assessed BNP concentration values in order to aid HF diagnosis in patients with dyspnea.

A study measuring ANF and BNP in emergency patients with dyspnea demonstrated that plasma BNP at admission had a higher accuracy than the ejection fraction of the left ventricle and ANF for the diagnosis of $\mathrm{HF}^{(9)}$. In this study, the authors defined $\mathrm{HF}$ based on clinical findings, conventional tests, response to treatment and assessment of the ejection fraction of the left ventricle by angiography.

Another study, assessing BNP in 250 patients who were admitted to the emergency room with dyspnea as the chief complaint, identified a significant discrepancy between BNP values in patients with and without $\mathrm{HF}$ diagnosis ${ }^{(8)}$. BNP value of $80 \mathrm{pg} / \mathrm{ml}$ was highly specific and sensitive for the diagnosis of HF. The negative predictive value of $\mathrm{BNP}<80 \mathrm{pg} / \mathrm{ml}$ was $98 \%$, thus excluding HF.

A major multicenter trial evaluated 1,586 patients with acute dyspnea in order to verify whether BNP may be deployed to differentiate patients with $\mathrm{HF}$ from those with other causes of shortness of breath ${ }^{(20)}$. The final results showed that BNP had good specificity and high negative predictive value to exclude the diagnosis of $\mathrm{HF}$, with an area under the receiver operating characteristic curve (ROC) of 0.91 , indicating excellent accuracy. The results also demonstrated an association between BNP plasma levels and severity of heart failure, in accordance with the functional classification of the New York Heart Association (NYHA). The same study corroborated that a simple BNP assessment was more accurate for the diagnosis of HF than Framingham criteria for $\mathrm{HF}$ and the American National Health and Nutrition Examination scale (NHANES) ${ }^{(20)}$.

Thus, the assessment of BNP may be deployed to exclude the diagnosis of $\mathrm{HF}$, mainly if the symptoms and signs are equivocal or mild and when they occur associated with comorbidities such as lung disease or obesity ${ }^{(11)}$.These diseases cause dyspnea, hindering the definition of cardiac etiology on clinical examination.

There is a positive correlation between BNP levels and enddiastolic pressure of the left ventricle and an inverse correlation with left ventricular function. One study indicated that these levels represent an independent assessment of ventricular function, precluding the need for any further costly test ${ }^{(18)}$. An investigation was conducted with ambulatory elderly population in order to establish reference intervals and concentration limits for decision making based on BNP and NT-pro-BNP assessment. It comprised 218 normal elderly patients and 474 with symptoms associated with HF. The upper limit of BNP reference range for healthy elderly was $\leq 97 \mathrm{pg} / \mathrm{ml}$. The cutoff value for decision making based on cardiovascular mortality following the HF population was approximately $170 \mathrm{pg} / \mathrm{ml}^{(1)}$.

BNP levels above $400 \mathrm{pg} / \mathrm{ml}$ characterize the clinical manifestations resulting from $\mathrm{HF}$, whereas values below $100 \mathrm{pg} / \mathrm{ml}$ practically exclude HF as the cause of symptoms. For values between 100 and $400 \mathrm{pg} / \mathrm{ml}$, clinical and other methods should be deployed for differential diagnosis ${ }^{(21)}$.

BNP assessment has proved to be cost-effective, inasmuch as the rapid diagnosis of $\mathrm{HF}$ obtained with its assessment decreases the time to initiate therapy, length of hospitalization and care costs.

Once HF is diagnosed, it becomes essential to characterize the type and degree of the cardiac involvement. In the elderly, numerous heart diseases, mainly coronary artery disease and aortic valve stenosis, may progress silently, therefore their identification is fundamental to a suitable approach. Thus, a two-dimensional echocardiography is recommended for all elderly patients with $\mathrm{HF}$ for diagnostic, etiologic, prognostic and functional comparison ${ }^{(3)}$.

Astudy investigated the use of BNP as a risk stratification strategy for cardiovascular disease by evaluating 10 biomarkers in 3,219 patients participating in the Framingham Heart Study: C-reactive protein (CRP), BNP, NT-pro-BNP, aldosterone, renin, fibrinogen, D-dimer, plasminogen activator inhibitor type 1, homocysteine and serum albumin/urinary creatinine. After seven years observing cardiovascular events, five biomarkers were predictors of death (BNP, CRP, serum albumin/urinary creatinine, homocysteine and renin) and two markers (BNP and serum albumin/urinary creatinine) were predictors of both death and cardiovascular risk ${ }^{(33)}$.

NT-pro-BNP has also been used for cardiovascular risk stratification in patients with acute coronary syndrome without ST segment elevation. It was confirmed that higher baseline NT-proBNP was associated with severe coronary artery disease and death in 1,141 patients with high troponin $\mathrm{T}^{(35)}$.

For the diagnostic approach of $\mathrm{HF}$ with an ejection fraction of the normal left ventricle, the European Consensus of Cardiology (2007) recommends the association of BNP assessment and $\mathrm{E} / \mathrm{E}^{\prime}$ ratio with echocardiography, hence increasing the area under the ROC curve of $83 \%$ to $95 \%$ diagnostic accuracy ${ }^{26)}$.

High BNP or NT-pro-BNP levels are not sufficient evidence for the diagnosis of heart failure with ejection fraction of the normal left ventricle, thus requiring additional noninvasive exams. 
For exclusion of $\mathrm{HF}$ with an ejection fraction of the normal left ventricle, a high negative predictive value would be below $120 \mathrm{pg} / \mathrm{ml}$ for NT-pro-BNP and $100 \mathrm{pg} / \mathrm{ml}$ for BNP. For diagnosis, a high positive predictive value of NT-pro-BNP would be as from $220 \mathrm{pg} / \mathrm{ml}$ and $200 \mathrm{pg} / \mathrm{ml}$ for BNP ${ }^{(26)}$.

Natriuretic peptides are especially recommended for exclusion of $\mathrm{HF}$ with an ejection fraction of the normal left ventricle, and not for diagnosis. Nevertheless, it should be complemented with other noninvasive investigation when applied for diagnostic purposes ${ }^{(26)}$. The use of serial BNP measurements to monitor the treatment of $\mathrm{HF}$ is not well established. Caution should be exercised when interpreting the variation in $50 \%$ concentration as related to medical therapy, insofar as there is a consistently high biological variation for both BNP and NT-pro-BNP(2).

A systematic review study indicates that the groups of patients with chronic HF monitored with NT-pro-BNP during therapy received more intensive care, more aggressive therapy and progressed with better quality of life, improvement in echocardiographic parameters and a few adverse events ${ }^{(14)}$.
The risk assessment of cardiovascular disease in the setting of primary prevention with BNP or NT-pro-BNP is unjustified. The increase in the concentrations of BNP or NT-pro-BNP is associated with higher mortality in the following 2-7 years in the studied populations. However, the benefits of therapy based on these assessments are uncertain ${ }^{(25)}$.

For early diagnosis of HF, plasma BNP or NT-pro-BNP may be helpful in patients with recent onset of dyspnea, improving diagnostic accuracy with a high negative predictive value ${ }^{(16)}$.

\section{CONCLUSION}

The evaluation of cardiac function, formerly restricted to the imaging area, currently has an excellent laboratory parameter, optimizing patient care. Furthermore, it is available in various assistance scenarios. The contribution of BNP or NT-pro-BNP for the diagnosis and prognosis of $\mathrm{HF}$ has been widely validated. The use of peptide assessment tends to be extended to other scenarios such as therapeutic evaluation and the detection of cardiovascular risk population.

\section{RESUMO}

O peptídeo natriurético tipo B (BNP) ou o seu precursor, a forma inativa do fragmento $N$ terminal do pró-BNP (NT-pró-BNP), são os parâmetros laboratoriais mais estudados atualmente no espectro da insuficiência cardíaca (IC). Por meio da mensuração de seus niveis no sangue, informações valiosas quanto a probabilidade, gravidade e prognóstico da doença podem ser reunidas. Esta revisão tem como objetivo descrever os determinantes biológicos, os fatores interferentes nas concentrações desses peptídeos, os valores de corte sugeridos para diagnóstico da IC e o uso deste biomarcador na avaliação da função cardíaca.

Unitermos: peptídeo natriurético tipo B; função cardíaca.

\section{REFERENCES}

1. ALEHAGEN, U.; GOETZE, J. P.; DAHLSTRÖM, U. Reference intervals and decision limits for B-type natriuretic peptide (BNP) and its precursor (Nt-proBNP) in the elderly. Clin Chim Acta, v. 382, n. 1-2, p. 8-14, 2007.

2. APPLE, F. S. et al. National Academy of Clinical Biochemistry and IFCC Committee for Standardization of Markers of Cardiac Damage Laboratory Medicine Practice Guidelines: analytical issues for biomarkers of heart failure. Clin Biochem, v. 41, n. 4-5, p. 222-6, 2008.

3. ARONOW, W. S. Echocardiography should be performed in all elderly patients with congestive heart failure. J Am Geriat Soc, v. 42, n. 12, p. $1300-2,1994$

4. BAYES-GENIS, A.; DEFILIPPI, C.; JANUZZI, J. L. Understanding
amino-terminalpro-B-typenatriureticpeptideinobesityAmJCardiol,v.101, n. 3A, p. 89-94, 2008.

5. BOOMSMA, F; VAN DEN MEIRACKER, A. H. Plasma A-and B-type natriuretic peptides: physiology, methodology and clinical use. Cardiov Res, v. 51, n. 3, p. 442-9, 2001.

6. CHANG, A. Y. et al. Associations among androgens, estrogens, and natriuretic peptides in young women: observations from the Dallas Heart Study. J Am Coll Cardiol, v. 49, n. 1, p. 109-116, 2007.

7. DANIELS, L. B.; MAISEL, A. S. Natriuretic peptides. J Am Coll Cardiol, v. 50 , n. 25 , p. 2357-68, 2007.

8. DAO, Q. et al. Utility of B-type natriuretic peptide in the diagnosis of congestive heart failure in an urgent-care setting. J Am Coll Cardiol, v. 37, n. 2, p. 379-85, 2001. 
9. DAVIS, M. et al. Plasma brain natriuretic peptide in assessment of acute dyspnoea. Lancet, v. 343, n. 8895, p. 440-4, 1994.

10. DE BOLD, A. J.; BRUNEAU, B. G.; KUROSKI DE BOLD, M. L. Mechanical and neuroendocrine regulation of the endocrine heart. Cardiov Res, v. 31, n. 1, p. 7-18, 1996.

11. DE LEMOS, J. A.; MCGUIRE, D. K.; DRAZNER, M. H. B-type natriuretic peptide in cardiovascular disease. Lancet, v. 362, n. 9380, p. 316-22, 2003.

12. FRIESINGER, G. C.; FRANCIS, J. Promises and perils of managed care for older patients with cardiac disease. Cardiol Clin, v. 17, n. 1, p. 67-77, 1999 .

13. GREWAL, J. et al. BNP and NT-proBNP predict echocardiographic severity of diastolic dysfunction. Eur J Heart Fail, v. 10, n. 3, p. 252-9, 2008.

14. JANUZZI, J. L. The role of natriuretic peptide testing in guiding chronic heart failure management: review of available data and recommendations for use.Arch Cardiov Dis, v. 105, n. 1, p. 40-50, 2012.

15. KIM, H.N.; JANUZZI, J. L. Natriuretic peptide testing in heart failure. Circulation, v. 123, n. 18, p. 2015-9, 2011.

16. KRUM, H. et al. 2011 update to National Heart Foundation of Australia and Cardiac Society of Australia and New Zealand Guidelines for the prevention, detection and management of chronic heart failure in Australia, 2006. Medical J Aust, v. 194, n. 8, p. 405-9, 2011.

17. LEUCHTE, H. H. et al. Clinical significance of brain natriuretic peptide in primary pulmonary hypertension. J Am Coll Cardiol, v. 43, n. 5, p. 764-70, 2004.

18. MAEDA, K. et al. Plasma brain natriuretic peptide as a biochemical marker of high left ventricular end-diastolic pressure in patients with symptomatic left ventricular dysfunction. Am Heart J, v. 135, n. 5, Pt 1, p. 825-32, 1998.

19. MAIR, J. et al. Head-to-head comparison of B-type natriuretic peptide (BNP) and NT-proBNP in daily clinical practice. Int J Cardiol, v. 124, n. 2, p. 244-6, 2008.

20. MAISEL, A. S. et al. Rapid measurement of B-type natriuretic peptide in the emergency diagnosis of heart failure. $N$ Engl J Med, v. 347, n. 3 , p. 161-7, 2002.

21. MAISEL, A. S. et al. Impact of age, race, and sex on the ability of B-type natriuretic peptide to aid in the emergency diagnosis of heart failure: results from the Breathing Not Properly (BNP) multinational study. Am Heart J, v. 147, n. 6, p. 1078-84, 2004.

22. MANZANO, L. et al. Diagnosis of elderly patients with heart failure. Eur J Heart Fail, v. 14, n. 10, p. 1097-1103, 2012.
23. MARTINEZ-RUMAYOR, A. et al. Biology of the natriuretic peptides. Am J Cardiol, v. 101, n. 3A, p. 3-8, 2008.

24. MCCULLOUGH, P. A. et al. B-type natriuretic peptide and renal function in the diagnosis of heart failure: an analysis from the Breathing Not Properly Multinational Study. Am J Kidney Dis, v. 41, n. 3, p. 571-9, 2003.

25. MYERS, G. L. et al. National Academy of Clinical Biochemistry Laboratory Medicine Practice guidelines: emerging biomarkers for primary prevention of cardiovascular disease. Clin Chem, v. 55, n. 2, p. 378-84, 2009 .

26. PAULUS, W. J. et al. How to diagnose diastolic heart failure: a consensus statement on the diagnosis of heart failure with normal left ventricular ejection fraction by the Heart Failure and Echocardiography Associations of the European Society of Cardiology. Eur Heart J, v. 28, n. 20, p. 2539-50, 2007.

27. REDFIELD, M. M. et al.Plasma brain natriuretic peptide concentration: impact of age and gender. J Am Coll Cardiol, v. 40, n. 5, p. 976-82, 2002.

28. ROSSI, A. et al. Natriuretic peptide levels in atrial fibrillation: a prospective hormonal and Doppler-echocardiographic study. J Am Coll Cardiol, v. 35, n. 5, p. 1256-62, 2000.

29. SENGENÈS, C. et al. Natriuretic peptides: a new lipolytic pathway in human adipocytes. FASEB J, v. 14, n. 10, p. 1345-51, 2000.

30. SILVER, M. A. et al. BNP Consensus Panel 2004: a clinical approach for the diagnostic, prognostic, screening, treatment monitoring, and therapeutic roles of natriuretic peptides in cardiovascular diseases. Congest Heart Fail, v. 10, n. 5, Suppl. 3, p. 1-30, 2004.

31. TEN WOLDE, M. et al. Brain natriuretic peptide as a predictor of adverse outcome in patients with pulmonary embolism. Circulation, v. 107, n. 16, p. 2082-4, 2003.

32. WAHL, H. G. et al. Elimination of the cardiac natriuretic peptides B-type natriuretic peptide (BNP) and N-terminal proBNP by hemodialysis. Clin Chem, v. 50, n. 6, p. 1071-4, 2004.

33. WANG, T. J. et al. Multiple biomarkers for the prediction of first major cardiovascular events and death. $N$ Engl J Med, v. 355, n. 25, p. 2631-9, 2006.

34. WILKINS, M. R.; REDONDO, J.; BROWN, L. A. The natriuretic-peptide family. Lancet, v. 349, n. 9061, p. 1307-10, 1997.

35. WINDHAUSEN, F. et al. N-terminal pro-brain natriuretic peptide for additional risk stratification in patients with non-ST-elevation acute coronary syndrome and an elevated troponin T: an Invasive versus Conservative Treatment in Unstable coronary Syndromes (ICTUS) substudy. Am Heart J, v. 153, n. 4, p. 485-92, 2007. 